\title{
Professional Autonomy as Centrality in Best Practices in Nursing
}

\author{
Autonomia profissional como centralidade em Boas Práticas de Enfermagem \\ Autonomía Profesional como centralidad en Buenas Prácticas de Enfermería
}

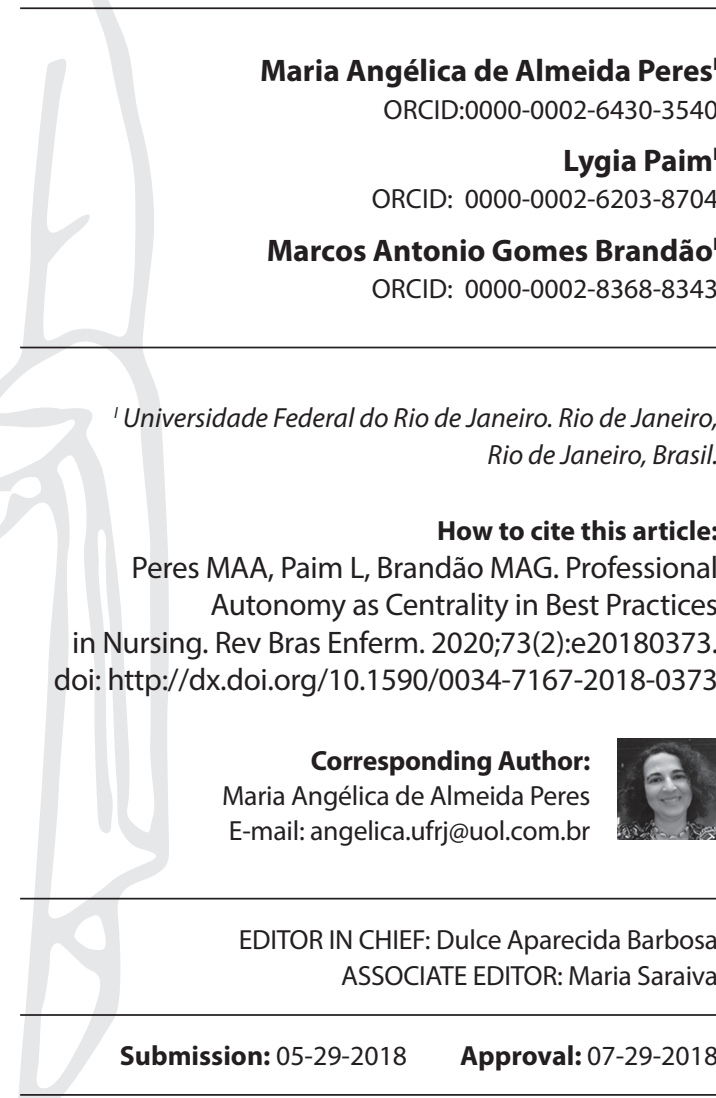

\begin{abstract}
Objectives: to reflect on professional, user and family autonomy as a centrality in Best Practices in nursing in Brazil. Methods: this is a theoretical-reflective study. Results: from a retrospective look at the creation and evolution of nursing autonomy in its knowledge and care practices, it exposes the use of autonomy in nursing care and foster the participation of the user and his family as the center of Best Practices in nursing. Final considerations: the text suggests the institutional commitment of health services to the formal postgraduate education of nurses and the prospect of more autonomy and quality for the expression of Best Practices in nursing.

Descriptors: Nursing; Professional Autonomy; Professional Practice; Nursing Care; History of Nursing.
\end{abstract}

\section{RESUMO}

Objetivos: refletir sobre a autonomia profissional, do usuário e da família como centralidade em Boas Práticas de Enfermagem no Brasil. Métodos: estudo teórico-reflexivo. Resultados: a partir de um olhar retrospectivo à criação e evolução da autonomia na Enfermagem em seus saberes e práticas assistenciais, expõe o uso da autonomia no cuidado de enfermagem e o fomento à participação do usuário e sua família como o centro de Boas Práticas de Enfermagem. Considerações finais: o texto sugere o compromisso institucional dos serviços de saúde com a educação formal pós-graduada dos enfermeiros e a prospecção de mais autonomia e mais qualidade para a expressão de Boas Práticas de Enfermagem.

Descritores: Enfermagem; Autonomia Profissional; Prática Profissional; Cuidados de Enfermagem; História da Enfermagem.

\section{RESUMEN}

Objetivos: reflexionar sobre la autonomía profesional, del usuario y de la familia como centralidad en Buenas Prácticas de Enfermería en Brasil. Métodos: estudio teórico-reflexivo. Resultados: a partir de una mirada retrospectiva a la creación y evolución de la autonomía en la enfermería en sus saberes y prácticas asistenciales, expone el uso de la autonomía en el cuidado de enfermería y el fomento a la participación del usuario y su familia como el centro de Buenas Prácticas de Enfermería. Consideraciones finales: el texto sugiere el compromiso institucional de los servicios de salud con la educación formal postgraduada de los enfermeros y la prospección de más autonomía y más calidad para la expresión de Buenas Prácticas de Enfermería.

Descriptores: Enfermería; Autonomía Profesional; Práctica Profesional;Cuidados de Enfermería; Historia de la Enfermería. 


\section{INITIAL CONSIDERATIONS}

The interest among nursing professionals to reflect on professional best practices requires a continuous attitude in the quest for higher quality care standards that depend on several elements that act in health as facilitators or impeders of these standards. Faced with the professional commitment to maintain bioethical principles in the care of health service users, the Best Practice in nursing is defined in each context to which it refers.

A conception is given to revisiting in the nursing literature the use of the concept of autonomy, in order to reflect on the professional autonomy and autonomy of the user and family as centrality in Best Practices in nursing in Brazil.

In a simplified way, the idea of autonomy is related to respecting the interest of each person in living their life according to their conception of what is good, having relevance in the biomedical and nursing literature, according to their own professional purposes. It is, therefore, the ability of a person that involves self-government, self-determination and compliance with his own rules ${ }^{(1)}$. Although it is an easy concept to understand, its practical application brings multidimensional impeders, of which the present article begins by reflecting in the perspective of the historicity of professional nursing autonomy.

\section{OBJECTIVE}

To reflect on professional, user and family autonomy as a centrality in Best Practices in nursing in Brazil.

\section{RESULTS}

\section{Diligence of professional autonomy and development of nursing care}

In this historical walk, it would be impossible not to confront Florence Nightingale's work of professional creation in the nineteenth century. From that point on, there must have reflection that autonomy was a concept and practice that was broadly emphatic about the revolutionary intention of building the nursing profession.

To make this profession as full as possible in the training designed by Nightingale, regarding the studies and concrete practices always focused on the development of nursing care actions to the people, focused on their health care situations, had their essay on the situation of the soldiers in the Crimean War. Thus, Nightingale dedicated herself to those actions aimed at the observational systematization and social qualification of the nursing profession, whose purpose, historically, came to be constituted according to the scientific foundations for a caring knowledge of ill people ${ }^{(2)}$.

Considering the historical framework in force at the time, lived the time of the dawn of the Renaissance, that is, primordial times of Arts and Sciences in this dawn of Nursing. Nightingale's notes, those that composed his illustrious report, are distinguished in their literary texts, with an approach of artistic and scientific characteristics, giving rise (we dare say) to the nuance of "Renaissance" writing to her work, in addition to the precursory nightingalean attitude of having experienced contrasts in the suffering settings of soldiers under their organization for professional nursing care $^{(3)}$.

Moreover, one should take into account the intrepidity of a woman of a distinctively noble family, specializing in Linguistics, Epidemiological Sciences and Arts, choosing to become the builder of an "art-science" profession in the meander of a time of characteristics still slave women. However, it is necessary to recognize a strictly centered struggle in the pioneering nightingalean woman, thus revealed, even in the intentionality of search for a certain professional nursing autonomy.

This reflection is due here to the temporality of nursing as a profession, created in the dawn of the Renaissance in Europe, which conflicted even by disregarding the dignity of women, hitherto domestic practitioners of the practice of caring for the ill. The framework of professional autonomy placed nightingalean nursing in the ethical principles of care, inseparably from best practices performed by professionals. A profession born with the mark of pioneering designed by Nightingale, in art and science, meant that this was certainly based on the concept of professional autonomy, as proposed deliberately by the intellective concept of caring for lives - "the most beautiful of Fine Arts"(3).

With Nightingale, the rising nursing emerges, providing for its founder and later for other women, a possibility of exercising individual autonomy, allowing in certain respects to be able to direct themselves in their interests of collaborating with an occupation in the which would make decisions based on reason and with some freedom of external factors. Obviously, social forces limited and still limited the capacity of individual autonomy. In nursing, the limits were imposed in relations with other professions, with institutions and with patients themselves.

As it is already known, the professional legacy of the Nightingalean nursing was brought to Brazil, at the invitation of the Government, by the sanitary doctor, researcher and current Director at the Brazilian Department of Public Health (DNSP), Professor Carlos Chagas. This legacy, in this case, refers to nursing thought as a science ${ }^{(4-5)}$.

American nurses came on a mission carried out by Ethel Parsons, with the support of the Rockefeller Foundation, implanting in Brazil the nursing already in the condition of profession with autonomy. These nurses were intended to A sensitive response from these courses was the increase in the scientific publications of articles and books in Brazil as expected create the desired Brazilian nursing training to function initially at the national level in the DNSP, according to the model of their country. Thus, the nursing course to be implanted in Brazil, still in the 1920s, when tropical diseases were mentioned, and poverty with high incidence in the city of Rio de Janeiro, the country's capital(5-6).

Nowadays, after the evolution of its 95 years of existence, the Nursing School, which since 1937 has been integrated with the Universidade Federal do Rio de Janeiro under the name of Escola de Enfermagem Anna Nery (Anna Nery School of Nursing), opens up the possibility of reading that this professional autonomy was already established as a strong influence on what can be called a preamble to the "Best Practices in nursing". This affirmation is also based on legislation that, from 1931 to 1949 , spread the "ananéri" standard as a desirable quality to other nursing schools, as a reference to best training practices. 


\section{More qualification in nursing education and extended autonomy}

Theoretically, the diffusion of a standard of education meant that all the schools of matched nursing would retain a certain similarity to the professional autonomy, thought since the creation of the nursing profession in England and developed for more than half a century in the United States. It can be said that the Brazilian group of nursing schools, until 1949, defended best practices of care based on this autonomy.

In this case, curricular standardization influenced nursing in the continuity of the presentation of best care practices in health care, impacting on the epidemiological health situation in Brazil, and built a new view of society for nurses in their profession. However, the required standards are dynamic and structured quantitatively and qualitatively in the time and space of nursing education, derived from evolutionary conditions, also diverse. The notion of a minimum nursing curriculum has marked another condition of qualitative diversity regarding the intentionality of a high level of knowledge, with theoretical approximation of what is required as best nursing care practices ${ }^{(5)}$.

Nursing theories, developed since the 1950s in the United States, were read and discussed in Brazil in the second half of the 1960s, enabling a freer attitude towards nursing actions, as they provide a guarantee of sustainable scientific reference for their intervention practices. A new conception about the practice of care led to the transition from doing to "thinking how to do", allowing the emergence of actions to encourage the participation of people in their care based on theories and the access of nurses to postgraduates, initially in lato sensu courses, while the supply of the stricto sensu level was being organized in the country ${ }^{(7)}$. A sensitive response from these courses was the increase in the scientific publications of articles and books in Brazil as expected.

One of the most visible benefits to the higher level professions in Brazil was the offering of stricto sensu postgraduate courses from the 1970s (Master's degree) and 1980 (Doctoral degree), which has been intensively used by nursing, although occupying place mainly reserved for educational institutions $s^{(7)}$.

Although the studies and researches of nursing with technological production advanced exponentially with the results of postgraduate courses, the health services were not always able to absorb for their use; the knowledge of them derived. Also, the infrastructure of most health services found it difficult to sustain the impact brought with the qualified change of the new nursing worker from these courses, which did not allow the advancement of professional autonomy in correspondence with the new acquired knowledge.

Thus, two factors of vulnerability to professional autonomy were established. The first is the desolation of a return to the care setting without corresponding operational practices by not encouraging the implementation of new theorized practices; the second, the discouragement of not having career plans corresponding to the academic advances obtained by the worker. What can be observed, in general, in the current situations, is that the nursing worker is faced with structural and functional inadequacies of the health service, and the processes and products of his postgraduate learning are requiring adjustments to the nature of reality in this return.
In this sense, best practices that would come from this postgraduate training are contained, although the continuous improvement by updates of the entire nursing team is an essential condition, since it will be necessary to make decisions regarding the competent; therefore, corresponding to best practices of nursing care.

\section{Lack of nursing research focused on the context of care practice}

Although the scientific production grew with the beginning of the postgraduate courses and the Nursing Research Groups were already organized, the research was still incipient, due to the fact that at this stage, the first Brazilian researches produced were restricted to isolated research and linked to scientific research, mostly as a thesis for obtaining a Doctoral degree, according to Teaching Tests ${ }^{(7)}$. It was in these studies and publications that, from the academic point of view, constituted Best Practices in nursing.

There are different factors that interfere in the centrality of best practices of nursing care in the health services, besides the emptiness of the nursing research in the environments of care practice. Among these factors, the institutional commitment to receive the professional that has left for studies and give him the condition to implant innovations to promote the quality of the care is emphasized. The bureaucratic place, which is often reserved for the postgraduate professional who returns to the health service, increasingly distances him from the necessary professional intimacy with users and their families - an approximation that would motivate him to enrich the knowledge of nursing and the theorization obtained in the course done, capable of revitalizing the thinking and knowing care, linked to his activities of studies and researches.

The expectation of those who leave for a postgraduate course is, at the very least, return to service with the willingness to make something innovative happen, transforming everyday practice, by adding quality to the service provided. Such quality depends on the professional autonomy to guarantee autonomy of the user and his family as the central point of care practice.

Professional autonomy for graduates or postgraduates has a relevant role and should be a central issue for the development of best nursing care practices. Evidence has shown that autonomy in the workplace is a predictor of retention at work and of nurses' satisfaction, which is significantly associated with the permanence of the newly formed in their field of work. A study conducted in Canada with 17,437 nursing professionals demonstrated the increased chances of developing depression and absences from work when professional autonomy was found to be reduced ${ }^{(8)}$.

The recognition of the preponderant role of professional autonomy for care providers cannot subtract the emphasis to be given to autonomy of care subjects ${ }^{(9)}$. If the goal of professional autonomy, conceived in the times of the beginning of the nursing construction and preserved until our days, was fundamental to the evolution of the ways of caring, today it guarantees us that, next to it, the requirement of the user's autonomy emerges and its family, without which there is an incompleteness of comprehensive care.

Contrary to the participation and autonomy of the user, for a long time, even with the use of nursing care plans already implanted 
by nurses, to be fulfilled by the whole team, the participation of the person cared for or his relatives was limited. The prevailing conviction was a clear separation between the decision and the formulation of the plan of care and the application of it as an opportunity and freedom for the user to decide and act on his care with their families. There was a limited margin of participation, making the user passive before the care offered.

The idea of individual autonomy of the user and of their families has been connected by many times to the informed consent for the accomplishment of some practices of care that bring more risks. Such consents function as defenses for practitioners and some expression of the autonomous desire of the subject of care. However, this perspective limits the broader perspective of autonomy ${ }^{(1)}$.

Nursing care, having as profile best practices, does not have as its centrality autonomy in the relations with the person assisted. Such positioning by the nurse requires a cognitive and social involvement in commitment to actions linked to the value of the relationship based on subjectivity.

Although in possession of its professional autonomy, for a long time nursing remained generous in the relationship with the user and the family. However, in relation to the user, nursing has learned to remain technically empowered. This objectivity in care, as an element of their real empowerment, was translated in response to the passivity of both the user and the families ${ }^{(9)}$. Today, it is expected that the centrality of nursing will be established in the production of more autonomy to have as allies to the nursing care itself these team members - users and their families. The logic of this relationship requires a closer relationship between nursing professionals and users of health services, and in turn, a certain detail of the nursing problems of each user, in their human singularity, allowing to recognize that also the organization and comfort environment contributes to the physical-functional condition, producing a level of well-being in health care, expressing participatory connotation in the quality of influence generated from this ambience as a therapeutic instrument. The nurse moves with the nursing team, as well as with users and their families, in the consideration of the knowledge of this predictable architecture in the orchestration of their professional work. It is, in fact, an essential condition for the exercise of Best Practices in nursing, the anticipated conduction of an environment seen as an instrumental part of the therapeutic sense of caring for people. The outlined and participative care carried out by the nursing team must also be coordinated to integrate the therapeutic care provided to users and their families, giving a healthy response to the workers and users of the health service.

It should be noted that there are multiple factors challenging the construction of Best Practices in nursing and, therefore, these practices do not lack theoretical concepts that guide and explain them. From the present perspective, the authors of this reflection conceive the existence of Bests Practice in nursing and if this practice is focused on the individual autonomy (of user and his family).

Organizational hierarchy of health institutions is potentially limiting autonomy, privacy, access to visits and feeding regimes ${ }^{(1)}$. Such factors are difficult or even impossible to circumvent fully, but can be worked out, in the interest of building a more comprehensive care of a more singular, co-responsible and welcoming plan.
The professional coexistence that only the nurse has because of his professionalism, "being together", can be the power that fits him, for his exclusivity in the health service social space, precisely due to the inevitable sharing, in the continuum of the uninterrupted 24 hours ${ }^{(10)}$. This interactional "being together" generates a certain intimacy and professional confidence, due to the uninterrupted relationship"nurse-user", to such a degree that the form of dialogical understanding, the similarity in the gesture and verbal language in the understanding and anticipation of questions, in the affinity to relate a nursing problem with the sensitive expressions attributed to the way of feeling of the user and his family. For all this, there is an interpretative connection that is built on strengthening the therapeutic set that is underway in the health team ${ }^{(9)}$. Expressions of care itself establish professional nursing connections with users and families that, only very extraordinarily, could counteract the search for the therapeutic position of a care plan of care.

Even for this reason, key to nursing knowledge lies in us, if we found ourselves in our clear power to empower users, in our dealing with subjectivity and intersubjectivities. Thus, there will jump from waiting for passive responses of users to a nursing performed without the subjection of these people and their families.

Passivity of users and their families has been fueled by the paternalistic tradition of therapeutic relationships in health. Paternalism involves the choice made by health professionals about treatments that they themselves consider to be the best interest of the user ${ }^{(1)}$. A more careful look at the very concept of "human needs" is fundamentally built from the outside to the user's interest. In the paternalistic perspective, the needs are identified from the professional standards of decision on what is necessary, and then are served in the interest of what the professional judges as the best for the subject of care.

Once ratified by the conventionally accepted modes of nursing care, the paternalistic view no longer shows itself capable of meeting the real longings of a system that considers the need to construct best care practices. Nowadays, encouraging autonomy of caregivers and caregivers has occurred as a demonstration of the evolution of health knowledge, of the expansion of the use of integrated knowledge of the social sciences and of the technological dynamics of nursing care itself.

When it comes to the professional autonomy of nurses in the participatory construction of health service users, the nursing technologies themselves provided that they are light or light-hard, require participation of the person to be cared for and some of them even extend to the participation of family members, companions or not. This participatory transformation promotes the person cared for, extrapolates the technical limit of execution of the care itself; and its nucleus is transposed to the ethical-political scope of concrete participatory rights encouraged by the nurse that necessarily fosters their protagonism.

Reflection makes us see that Best Practices in nursing are triggered by the empowerment of the user and his family, under the personalized situation circumstance that will not be the ethicalsocial change, so called in health-nursing.

There must be reflection on the numerous ways in which autonomy can acquire centrality in Best Practices in nursing. Probably, the liberal and individual idea of autonomy is neither sufficient nor appropriate to overcome the limitations of the 
context of health care ${ }^{(9)}$, which leads us to an understanding of relational autonomy as closer to the aforementioned best practices.

Relational autonomy refers to a term derived from feminist arguments and used to describe relationships and social contexts of values, relationships, and power structures that give information about an individual's autonomous decision-making. The perspective of relational autonomy equips professionals and users to see which actors and social contexts are influencers of decision-making, including realizing the central role that human relations play in influencing decision-making, shaping people's autonomy ${ }^{(1)}$. In the Brazilian Unified Health System (SUS - Sistema Único de Saúde), relational autonomy seems to be contained in policies and initiatives that seek to build an autonomous relational, social and citizen consciousness, among them: National Policy of Humanization (Política Nacional de Humanização is a public policy in SUS aimed at the activation of devices that favor humanization actions in health care and management in Brazil), Unique Therapeutic Projects (Projetos Terapêticos Singulares is a set of proposals for articulated therapeutic behaviors for an individual or collective subject) and Expanded Clinic.

In relation to care, the concept of relational autonomy supports the abilities of individuals to make and participate in health care choices, socializing and integrating people to the environment where care takes place ${ }^{(1)}$.

Whatever the setting of care practice and its systematization, from the point of view of health service classifications, the planned nursing care to users should not dispense with the quest for the relational autonomy of these. By taking relational autonomy as the fundamental characteristic of any and all nursing care - especially among users and their families, relational autonomy in this case comprises the core of Best Practices in nursing.

\section{FINAL CONSIDERATIONS}

If there is a possibility of summarizing in this article what can be a contribution of inexhaustible value, this is configured in the declared interest to open paths of reflection on what is and what is not, an adjustment of Best Practices in nursing. To do so, we are urged to rephrase an issue that has accompanied us since the beginning of this reflective study. How to overcome the preponderance of the rationality of our time, to reach Best Practices in nursing? This questioning opens a glimmer in the text about autonomy of people we care professionally. The intentionality of seeking ways of overcoming rationalities, by itself, already translates into ethics in nursing care. We should also reflect: in what way do we have, in nursing dealing with the environment, since it certainly functions as a therapeutic instrument of nursing care?

The emergence of values of immaterial wealth and not only to establish it in warm technically explicable reasons, is the transformation that, necessarily, autonomy, in its relational character, will be governing the choice of one of the best conditions to the construction of best practices of care as centrality in nursing.

\section{REFERENCES}

1. Cole C, Wellard S, Mummery J. Problematising autonomy and advocacy in nursing. Nurs Ethics. 2014;21(5):576-82. doi: 10.1177/0969733013511362Wallace

2. DJ, Kahn, JM. Florence Nightingale and the Conundrum of Counting ICU Beds. Crit Care Med [Internet]. 2015 [cited 2018 Mar 21];43(11):2517-18. Available from: https://insights.ovid.com/crossref?an=00003246-201511000-00036

3. Nightingale F. Notas sobre enfermagem. Cortez; 1989.

4. Carvalho V. About the professional identity in Nursing: punctual reconsiderations in philosophical vision. Rev Bras Enferm. 2013;66(spe):2432. doi: 10.1590/S0034-71672013000700003

5. Peres MAA, Almeida Filho AJ, Paim L. Nursing historicity in the spaces of power in Brazil. Hist Enferm Rev Eletr [Internet]. 2014 [cited 2018 Mar 21];5(1):83-94. Available from: http://www.here.abennacional.org.br/here/vol5num1artigo7.pdf

6. Ribeiro AG, Rosa TCS, Blass LMS. A formação de enfermeiros no contexto da reorganização do sistema de saúde. Rev Cad Estud Soc Pol. 2016 [cited 2018 Mar 21];1(1):126-62. Available from: http://www.periodicos-ppgspuvv.com.br/ojs/index.php/cesp/article/view/21/11

7. Mendes ALTM, Aperibense PGGS, Almeida Filho AJ, Peres MAA. Nursing master's program at Anna Nery School 1972-1975: singularities of graduating and challenges in its implementation. Esc Anna Nery. 2015;19(1):11-17. doi: 10.5935/1414-8145.20150002

8. Enns V, Currie S, Wang J. Professional autonomy and work setting as contributing factor to depression and absenteeism in Canadian nurses. Nurs Outlook [Internet]. 2015[cited 2018 May 27];63(3):269-77. Available from: http://151.236.52.15:8080/xmlui/bitstream/ handle/123456/3877/v55n2a16.pdf?sequence=1

9. Lindberg C, Fagerströn C, Sivberg B, Wilman A. Concept analysis: patient autonomy in a caring context. J Adv Nurs. 2014;70:2208-21. doi: 10.1111/jan.12412

10. Loyola CM. The inclusion of the subjects as a way to psychiatric care. Esc Anna Nery [Internet]. 2000 [cited 2018 May 26];4(1):129-37. Available from: http://www.redalyc.org/pdf/1277/127718313015.pdf 